\title{
The Effect of the Solidification Rate, Sulfur and Titanium Contents on the Graphite Structure in Unidirectionally Solidified Cast Iron*
}

\author{
By Chisato YOSHIDA,** Toshimasa SAKAMOTO,** Katsuyuki YOSHIKAWA ${ }^{* *}$ \\ and Hisashi TAKADA**
}

\begin{abstract}
Synopsis
The effects of the addition of two impurity elements (sulfur and litanium) and of the solidification rate on the graphite structure of iron-graphite eutectic were investigated by the unidirectional solidification method. The effect of sulfur and titanium on the transition of lamellar-colony-eutectic cell is discussed.

The rosette graphite was formed by the fine/coarse transition in a eutectic cell. The formation mechanism of rosette graphite was studied.

The effect of sulfur or titanium on the intergraphite spacing was also sludied.

A diagram of the unidireclional solidification structure was drawn from the observation of graphite structure which was changed with the solidification conditions and additions. This diagram will be useful in obtaining some fundamental knowledge of graphite structure formation.

New material - layer graphite cast iron plate-was made by using the unidirectional solidificalion technique and hot rolling. The physical anisotropic characteristics are described.
\end{abstract}

\section{Introduction}

The investigation of solidification phenomena in unidirectionally solidified cast iron has been carried out by Lakeland, ${ }^{1,2)}$ Nieswaag and Zuithoff, ${ }^{3-5)}$ Sayama et al. ${ }^{6-8)}$ Ibaragi et al. ${ }^{9)}$ and Owadano et al. ${ }^{10)}$ The authors ${ }^{11-15)}$ have also investigated the effect of the solidification rate and the addition of impurity elements to the graphite structure of relatively pure iron-carbon and iron-carbon-silicon eutectic alloy when the unidirectional solidification method is applied. As it is possible to control the solidification conditions with this technique, it is useful for a material such as cast iron in which the solidification structures are changed by many factors in complicated ways. Sulfur and titanium were chosen as the impurity elements for this experiment, because these are typical impurity elements which have remarkable effects on the solidification structure and mechanical properties of cast iron.

The effects of sulfur ${ }^{12-14)}$ and titanium $^{15)}$ on the lamellar, colony and eutectic cell structure and on the transition of lamellar/colony/eutectic cell structure were investigated.

Graphite structure diagrams were drawn by using the results of observation of the various graphite morphologies. Various experiments on the effect of sulfur have been carried out using unidirectional solidification, but there have been very few studies on the effect of titanium.

In general, sulfur is a chemical element which makes the graphite flakes coarse and, on the contrary, titanium is an element which makes the graphite flakes fine. By using the diagram, the factors which control the graphite morphology might be extracted clearly.

The lamellar graphite structure which is aligned in a direction parallel to the solidification direction is interesting for composite materials. Hot rolling of unidirectionally solidified cast iron was tried in order to align the lamellar graphite further. Electrical resistance ${ }^{16)}$ and thermal diffusivity ${ }^{17)}$ in this new material were measured.

\section{Method of Unidirectional Solidification}

The chemical composition of iron-carbon alloy is given in Table 1. Electrolytic iron, pure graphite and metallic silicon were melted in a high frequency induction furnace and cast into rods in a metallic mold.

The amount of sulfur added was $0.01 \sim 0.2 \%$. The required sulfur content was obtained by the addition of Fe-S alloy. Sulfur content is indicated as the amount added. The amount of titanium added was $0.02 \sim 0.2 \%$. Titanium content is indicated both as the amount added and as the analytical value.

The unidirectional solidification experiments were carried out in a vertical-type apparatus as shown in Fig. 1. The furnace was held at $1250{ }^{\circ} \mathrm{C}$ by a heater composed of silicon carbide. A water-cooled coil was placed in the lower portion of the heater. Some thermal gradient was given between the center part and the lower part of the furnace. The melt in an alumina crucible was slowly lowered down from the furnace. The temperature gradient was about $20^{\circ} \mathrm{C} / \mathrm{cm}$ and the solidification rate was from 0.4 to $20 \mathrm{~cm} / \mathrm{hr}$. In order to measure the temperature precisely during the unidirectional solidification, a thermocouple composed of one $\mathrm{Pt}$ wire and five $\mathrm{Pt}$ $\mathrm{Rh}$ wires was used.

The unidirectionally solidified material was $37 \mathrm{~mm}$ in diameter and $120 \mathrm{~mm}$ in length. The middle part of the specimen which had been sectioned longitudinally was used for the metallographic examination.

In the unidirectionally solidified specimen, dis-

Table 1. Chemical composition of $\mathrm{Fe} \mathrm{C}$ and $\mathrm{Fe}-\mathrm{C}-\mathrm{Si}$ alloys. (\%)

\begin{tabular}{cccccc}
$\mathrm{C}$ & $\mathrm{Si}$ & $\mathrm{Mn}$ & $\mathrm{P}$ & $\mathrm{S}$ & $\mathrm{Sc}$ \\
\hline 4.45 & 0.008 & 0.005 & 0.003 & 0.011 & 1.04
\end{tabular}

* Originally published in Imono (Journal of The Japan Foundrymen's Society), 51 (1979), 76 and 54 (1982), 277, in Japanese. English version received on April 17, 1984; accepted in the final form on July 3, 1984. (C) 1985 ISIJ

** Central Research Laboratory, Kobe Steel, Ltd., Wakinohama-cho, Chuo-ku, Kobe 651. 
continuous flaky graphite which is called band structure has sometimes been observed vertically to the solidification direction. Since band structure is caused by temperature fluctuation, ${ }^{3)}$ in this experiment it was avoided completely by precise control of the furnace temperature.

\section{Effect of Solidification Rate on the Graphite Structure}

Photograph 1 shows the lamellar-colony-cutectic cell structure parallel to the solidification direction when no sulfur is added. At a solidification rate of $0.55 \mathrm{~cm} / \mathrm{hr}$ (a), the lamellar graphite structure was

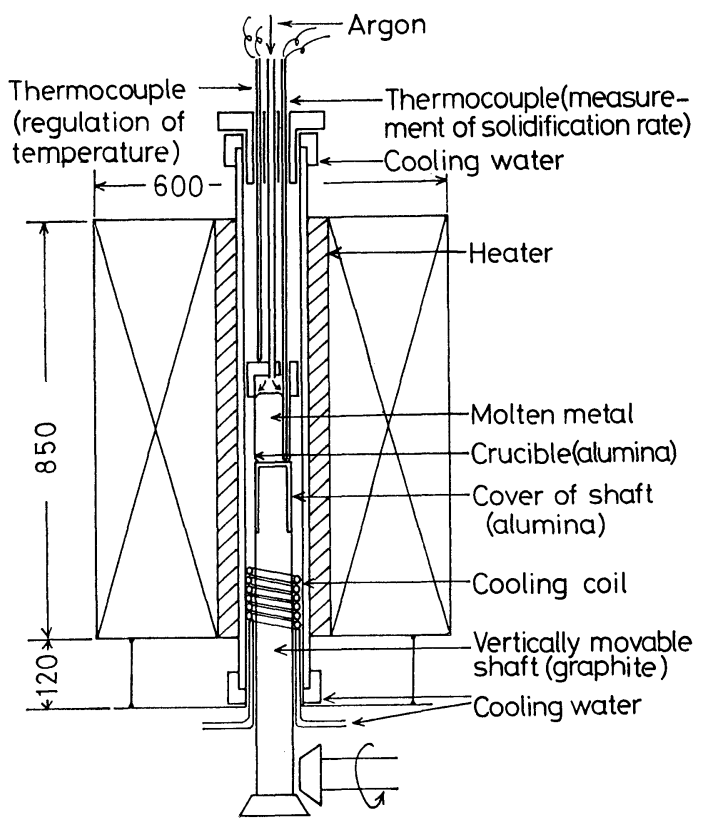

Fig. 1. Unidirectional solidifying apparatus. observed. The graphite flakes are parallel to the solidification direction. The average lamellar spacing was 120 to $130 \mu$. When the solidification rate was increased to $0.75 \mathrm{~cm} / \mathrm{hr}$ (b), the lamellar spacing decreased and the branching of graphite flakes increased. But the graphite flakes were still parallel to the solidification direction.

Photograph 1(c) shows graphite structure at $0.94 \mathrm{~cm} / \mathrm{hr}$. Though the degree of graphite alignment is relatively poor, this graphite structure is considered to belong to the lamellar structure, because no colony or eutectic cell boundary is observed.

At the last part of this unidirectionally solidified specimen $(0.94 \mathrm{~cm} / \mathrm{hr})$, the colony structure was formed (d). In this paper the colony structure is defined as the structure consisting of uniform fine graphite without eutectic cell boundaries. At a rate of $1.3 \mathrm{~cm} / \mathrm{hr}$ (e), the shape of the eutectic cell becomes long and elongated along the length of the unidirectionally solidified specimen. This is because the direction of heat flow is unidirectional from top to bottom during the solidification. As the structure in Photo. $1(\mathrm{e})$ is a eutectic cell structure, the colony structure is supposed to be formed at the solidification rate between $0.94 \mathrm{~cm} / \mathrm{hr}$ and $1.3 \mathrm{~cm} / \mathrm{hr}$. When the solidification rate is over $2 \mathrm{~cm} / \mathrm{hr}((\mathrm{f}) \sim(\mathrm{h}))$, the eutectic cell boundary becomes clearer and the shape of the eutectic cell changes from a large, extended one to a small, spherical one with an increase in the solidification rate.

Photograph 2 is the lamellar-eutectic cell structure when the amount of sulfur added is $0.03 \%$. The lamellar structure was formed at a solidification rate of $0.51 \mathrm{~cm} / \mathrm{hr}$ (a). The lamellar graphite flakes are slightly crooked at a rate of $0.88 \mathrm{~cm} / \mathrm{hr}$ (b) and $0.95 \mathrm{~cm} / \mathrm{hr}$ (c). In Photo. 2(d), some graphite

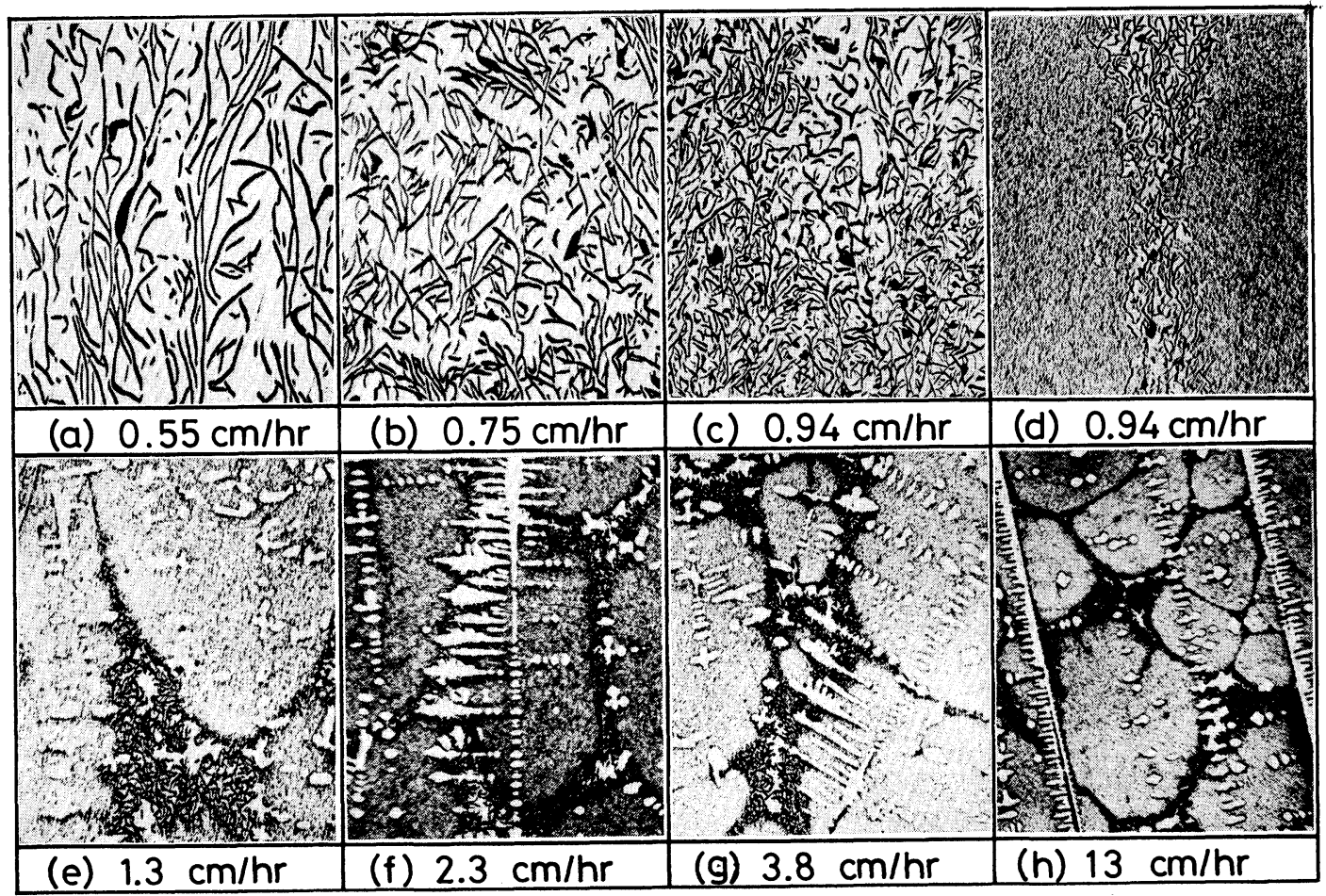

Photo. 1. Effect of solidification rate on graphite structure. $(0 \% \mathrm{~S}$ addition $)(\times 20)(\times 1 / 2)$ 


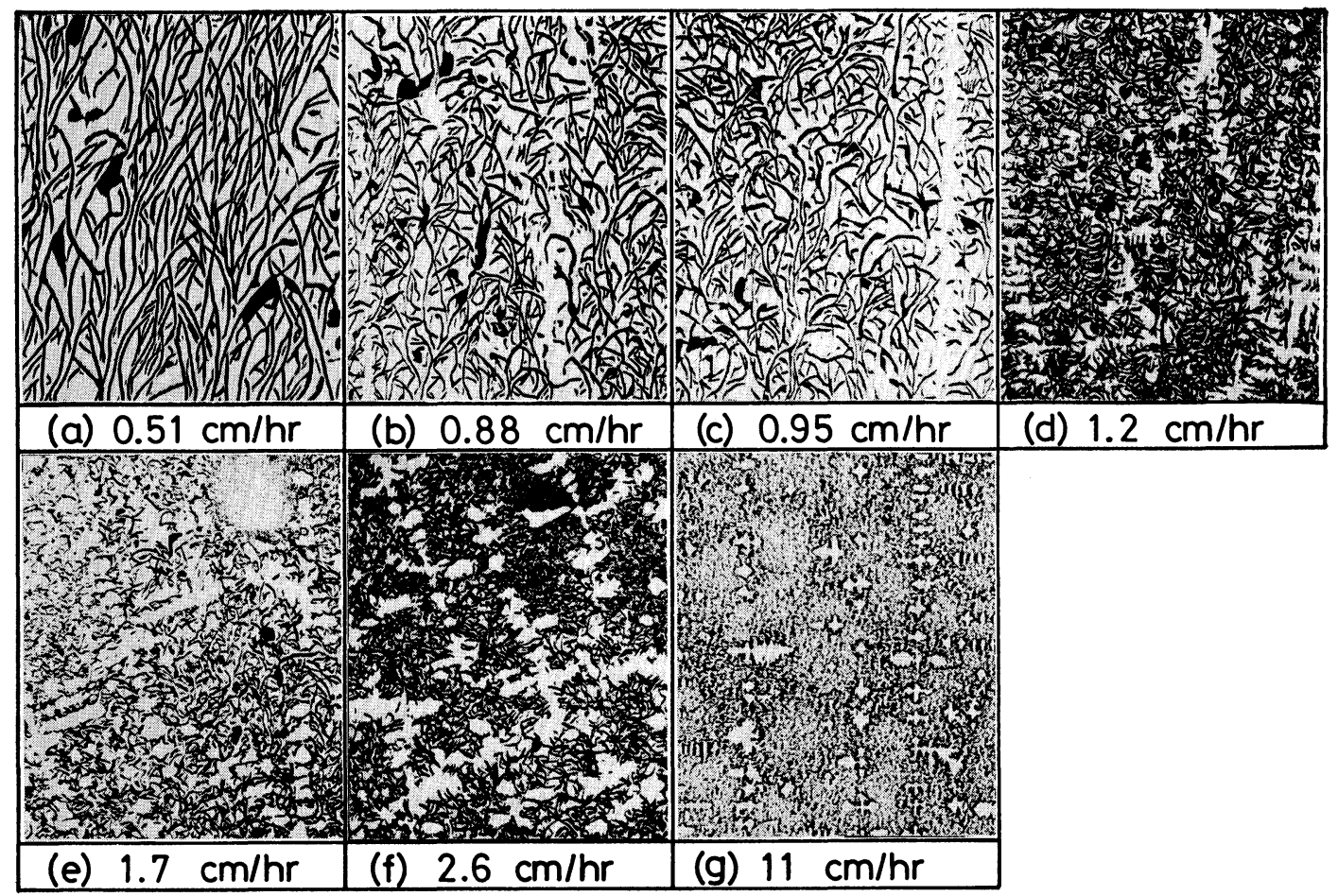

Photo. 2. Effect of solidification rate on graphite structure. $(0.03 \% \mathrm{~S}$ addition $)(\times 20)(\times 1 / 2)$

flakes are branched and curved all the more. It is difficult to distinguish whether this graphite structure belongs to the lamellar structure or the eutectic cell structure. No colony structure was found in Photo. 2. At the solidification rate between $1.7 \mathrm{~cm} / \mathrm{hr}$ (e) and $2.6 \mathrm{~cm} / \mathrm{hr}$ (f), the structure is a eutectic cell which is composed of austenitic dendrite and large flaky graphite, but the eutectic cell boundary is not very clear. When the solidification rate is increased to $11 \mathrm{~cm} / \mathrm{hr}(\mathrm{g})$, the graphite becomes fine and the eutectic cell boundary becomes somewhat clearer.

\section{Effect of Sulfur on the Graphite Structure}

\section{Lamellar Structure}

Photograph 3 shows the effect of sulfur on the lamellar structure. When the sulfur content is less than $0.03 \%$, graphite flakes grow parallel to the solidification direction. In this paper, this structure is called "aligned lamellar". But graphite flakes are crooked or branched at a higher sulfur content. These structures are called " non-aligned lamellar" in this paper. At $0.2 \% \mathrm{~S}$, graphite flakes are visibly discontinuous. From the microscopic observation, the transition of aligned/non-aligned lamellar structure is affected by the solidification rate. With an increasing solidification rate, aligned/non-aligned lamellar transition moves to higher sulfur content.

\section{Effect of Sulfur on the Lamellar Graphite Spacing}

Ibaragi et al. ${ }^{9)}$ explained that the graphite spacing was increased and graphite flakes were made coarse by the addition of sulfur, because the grooves of austenite at the solid-liquid interface are deepened by the sulfur, which makes for easy precipitation of carbon through the austenite phase (Fig. 2(a)).

Sayama et al. ${ }^{6}$ ) obtained the following equation, which could apply to the partially cooperative growth model of the eutectic alloy.

$$
\begin{aligned}
& \lambda^{2} \cdot V=A \cdot a_{\beta}^{6 / 5} \cdot a_{\alpha}^{-1 / 5} \quad(A: \text { constant }) \\
& a_{\alpha}=T_{L} \cdot \sigma_{\alpha L} \sin \theta_{\alpha} / L_{\alpha} \\
& a_{\beta}=T_{E} \cdot \sigma_{\beta L} \sin \theta_{\beta} / L_{\beta}
\end{aligned}
$$

where, $\sigma_{\alpha L}$ : interfacial energy between austenite and melt

$\sigma_{\beta L}: \quad$ interfacial energy between graphite and melt

0 : contact angle.

The equations and marks are shown in the Refs. 6) and 7). In the examination of sulfur segregation by EPMA, it was assumed that the interfacial energy $\sigma_{\beta L}$ decreased considerably, as the sulfur was easy to segregate at the interface between graphite and melt. When $\sigma_{\beta L}$ decreases, $\sigma_{\alpha L}$ may increase from the interfacial energy balance. Therefore, with a decrease of $a_{\beta}$ and an increase of $a_{\alpha}$, the value of $\lambda^{2} \cdot V$ in the above equation decreases. This means that the lamellar spacing is decreased by sulfur at the same solidification rate (Fig. 2(b)).

According to the measurement by Nieswaag and Zuithoff, ${ }^{5)}$ lamellar spacing is increased by sulfur, but the spacing decreases over $0.02 \% \mathrm{~S}$ (Fig. 2(c)). In our experiment, ${ }^{12)}$ the lamellar spacing increased at contents of $0 \sim 0.05 \% \mathrm{~S}$, but it decreased at contents higher than $0.05 \%$ (Fig. 2(d)).

Results concerning the effect of sulfur on lamellar spacing differ widely among researchers. Yanagisawa and Maruyama ${ }^{18)}$ explained that the solid/liquid interface was apt to be affected by the non-steady 


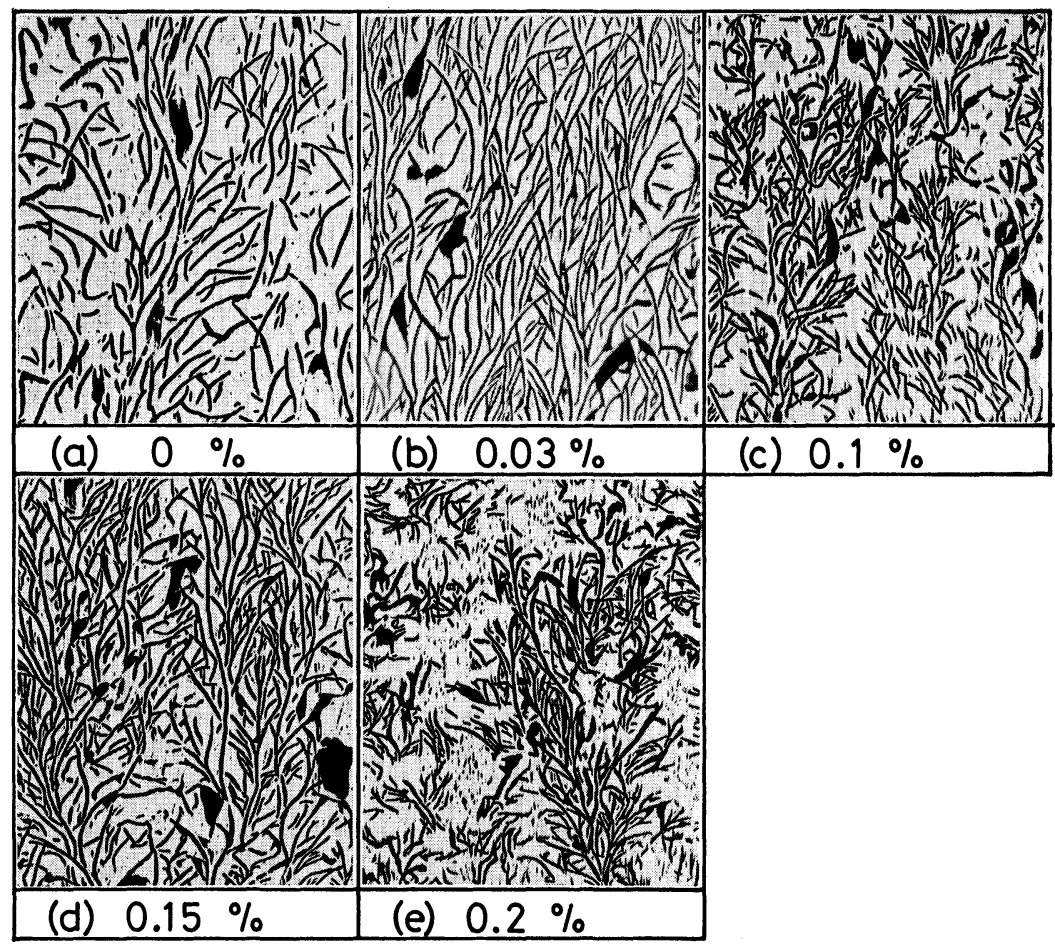

Photo. 3. Effect of sulfur on lamellar graphite structure. $(\times 20)(\times 1 / 2)$

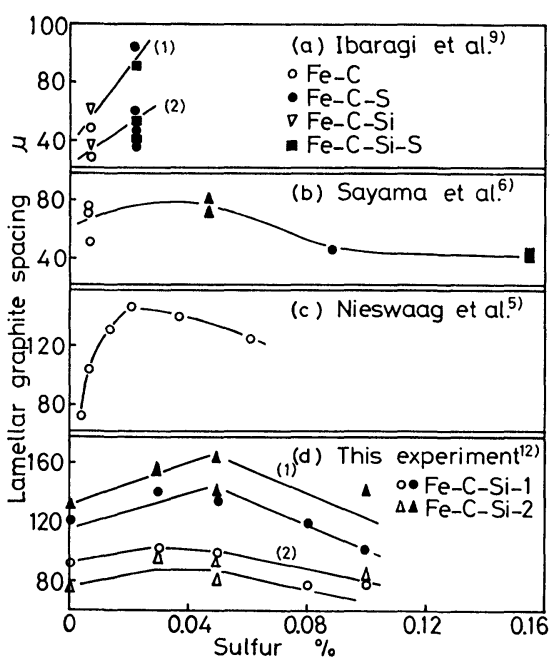

(1) Average of graphite spacing measured in both concentrated and other areas of graphite

(2) Graphite spacing measured only in areas of concentrated aligned graphite

Fig. 2. Effects of sulfur on the lamellar graphite spacing.

Table 2. Comparison of experimental conditions.

\begin{tabular}{|c|c|c|c|c|}
\hline & Ibaragi et al.9) & Sayama et al. ${ }^{6)}$ & Nieswaag and Zuithoff $\left.{ }^{5}\right)$ & This experiment ${ }^{12)}$ \\
\hline $\begin{array}{l}\text { Chemical } \\
\text { composition (\%) }\end{array}$ & $\begin{array}{l}\mathrm{Fe}-\mathrm{G} \\
\mathrm{C}: \quad 3.99 \sim 4.30 \\
\mathrm{Si}: \text { trace } \\
\mathrm{Fe}-\mathrm{C}-\mathrm{Si} \\
\mathrm{C}: \quad 3.30 \sim 4.27 \\
\mathrm{Si}: \quad 0.67 \sim 3.33\end{array}$ & $\begin{aligned} \mathrm{C}: & 4.2 \sim 4.3 \\
\mathrm{Si}: & 0.01 \\
\mathrm{Mn}: & 0.01 \\
\mathrm{P}: & 0.001 \sim 0.002\end{aligned}$ & $\begin{aligned} \mathrm{C}: & 4.2 \sim 4.3 \\
\mathrm{Si}: & 0.03 \sim 0.07 \\
\mathrm{Mn}: & 0.003 \sim 0.005 \\
\mathrm{P}: & 0.007 \sim 0.008\end{aligned}$ & $\begin{aligned} \mathrm{G}: & 3.75 \sim 3.91 \\
\mathrm{Si}: & 1.72 \sim 1.77 \\
\mathrm{Mn}: & 0.01 \sim 0.04 \\
\mathrm{P}: & 0.003 \sim 0.005\end{aligned}$ \\
\hline S (\%) & $0.006 \sim 0.022$ & $0.007 \sim 0.449$ & $0.004 \sim 0.06$ & $0 \sim 0.1$ \\
\hline $\begin{array}{l}\text { Thermal gradient } \\
\left({ }^{\circ} \mathrm{C} / \mathrm{cm}\right)\end{array}$ & $20 \sim 90$ & 45 & 35 & 20 \\
\hline $\begin{array}{l}\text { Measurement of } \\
\text { graphite spacing }\end{array}$ & $\begin{array}{l}\text { Measured in cross } \\
\text { section }\end{array}$ & $\begin{array}{l}\text { Measured in cross } \\
\text { section }\end{array}$ & $\begin{array}{l}\text { Measured in } \\
\text { longitudinal section }\end{array}$ & $\begin{array}{l}\text { Measured in } \\
\text { longitudinal section }\end{array}$ \\
\hline
\end{tabular}

state of thermal gradient or concentration gradient in $\mathrm{Fe}-\mathrm{C}$ stable system. They also mentioned that the precipitation of $\mathrm{MnS}$ in the melt or the formation of inclusions in front of the solid/liquid interface should not be ignored. Though these problems are certainly important, it seems to be more necessary to discuss the chemical composition of the raw materials used in each experiment, the range of sulfur content, the thermal gradient and the method used for measurement of lamellar spacing.

These comparisons are summarized in Table 2 . Silicon content probably did not significantly affect graphite spacing. It is not necessary to consider the effect of $\mathrm{MnS}$ on the graphite spacing, because the manganese content is very low in each experiment. Even when the sulfur content increases, $\mathrm{MnS}$ does not precipitate, because it is below the product of solubility. ${ }^{19)}$ The contents of carbon and phosphorus are almost the same ( $\mathrm{C}$ is about $4 \%$ and $\mathrm{P}$ is under
$0.008 \%$ ). But the extent of sulfur content is interpreted differently by various researchers. This is a very important point.

There have been very few experiments on the effect of thermal gradient $G$ on the lamellar spacing. According to Okamoto's report, ${ }^{9)}$ however, the graphite morphology is not changed much by $G$ when $G$ is between $20^{\circ} \mathrm{C} / \mathrm{cm}$ and $75^{\circ} \mathrm{C} / \mathrm{cm}$.

From the above considerations, various measurement values are summarized in Fig. 2. It is recognized that the lamellar spacing increases at low sulfur contents, and decreases at high sulfur contents.

\section{Colony and Eutectic Cell Structure}

Photograph 4 shows the effect of sulfur on the colony structure. When only $0.005 \% \mathrm{~S}$ was added, the colony structure began to disappear, and changed to coarse graphite structure with the addition of $0.005 \%$ more sulfur. It was recognized that the 
colony structure disappeared with the addition of just a small amount of sulfur.

The colony structure was not formed uniformly along the length of the unidirectional specimen (specimen is $12 \mathrm{~cm}$ in length). Coarse graphite was formed suddenly in the unidirectional specimen. This sudden change of graphite is assumed to occur either because of the segregation of impurity elements, or because of slight fluctuation of thermal gradient, or of solidification rate during a unidirectional solidification. This phenomenon shows that fine/coarse graphite change occurs transitionally during a solidification.

Photograph 5 summarizes the effect of sulfur on the eutectic cell structure. When the solidification rate is $2.3 \mathrm{~cm} / \mathrm{hr}$, the fine/coarse graphite transition occurs between $0.01 \% \mathrm{~S}$ (b) and $0.03 \% \mathrm{~S}$ (c). At $0.01 \% \mathrm{~S}$ the rosette graphite was formed, but this structure was defined as a fine graphite structure because of high area percentage of fine graphite. When the solidification rate is $13 \mathrm{~cm} / \mathrm{hr}$, the fine/ coarse graphite transition occurs between $0.03 \% \mathrm{~S}$ (g) and $0.10 \% \mathrm{~S}(\mathrm{~h})$. Therefore, the sulfur content which causes this transition moves to higher content with an increase of solidification rate.

\section{Formation of Rosette Graphite ${ }^{13)}$}

When a small amount of sulfur was added, the graphite structure which consists of fine graphite in the center of a eutectic cell and a coarse graphite in the boundary area was observed. This structure is called rosette graphite. The fine/coarse graphite transition in a eutectic cell was investigated. Photograph 6 is a SEM photograph of rosette graphite. The graphite structure in a eutectic cell seems to be three-dimensionally continuous. It is assumed that graphite changes form fine to coarse at contents higher than $0.05 \% \mathrm{~S}$, because fine graphite disappears at this content.

In general, the solute content in liquid is concentrated in front of the solid/liquid interface with the growth of a solid state. Therefore, in the case

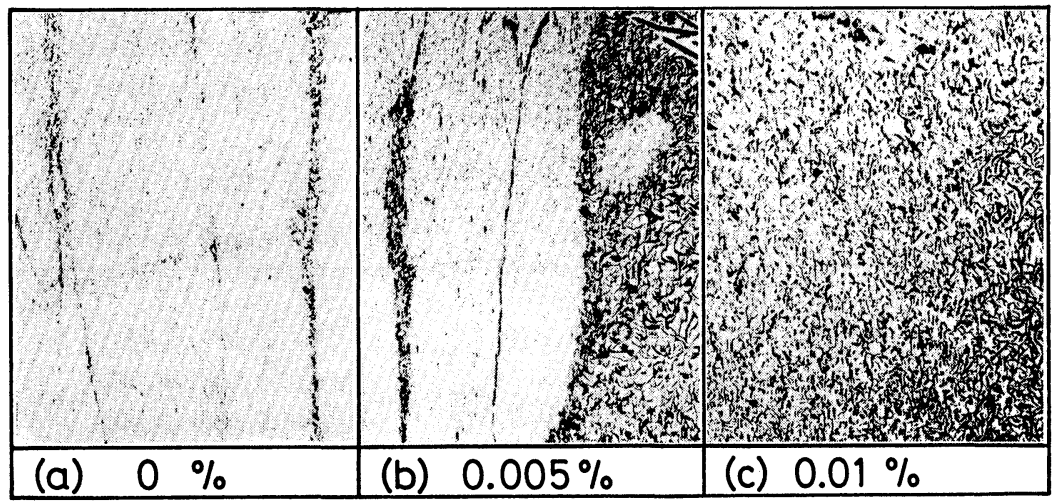

Photo. 4. Effect of sulfur on colony structure. $(\times 20)(\times 1 / 2)$

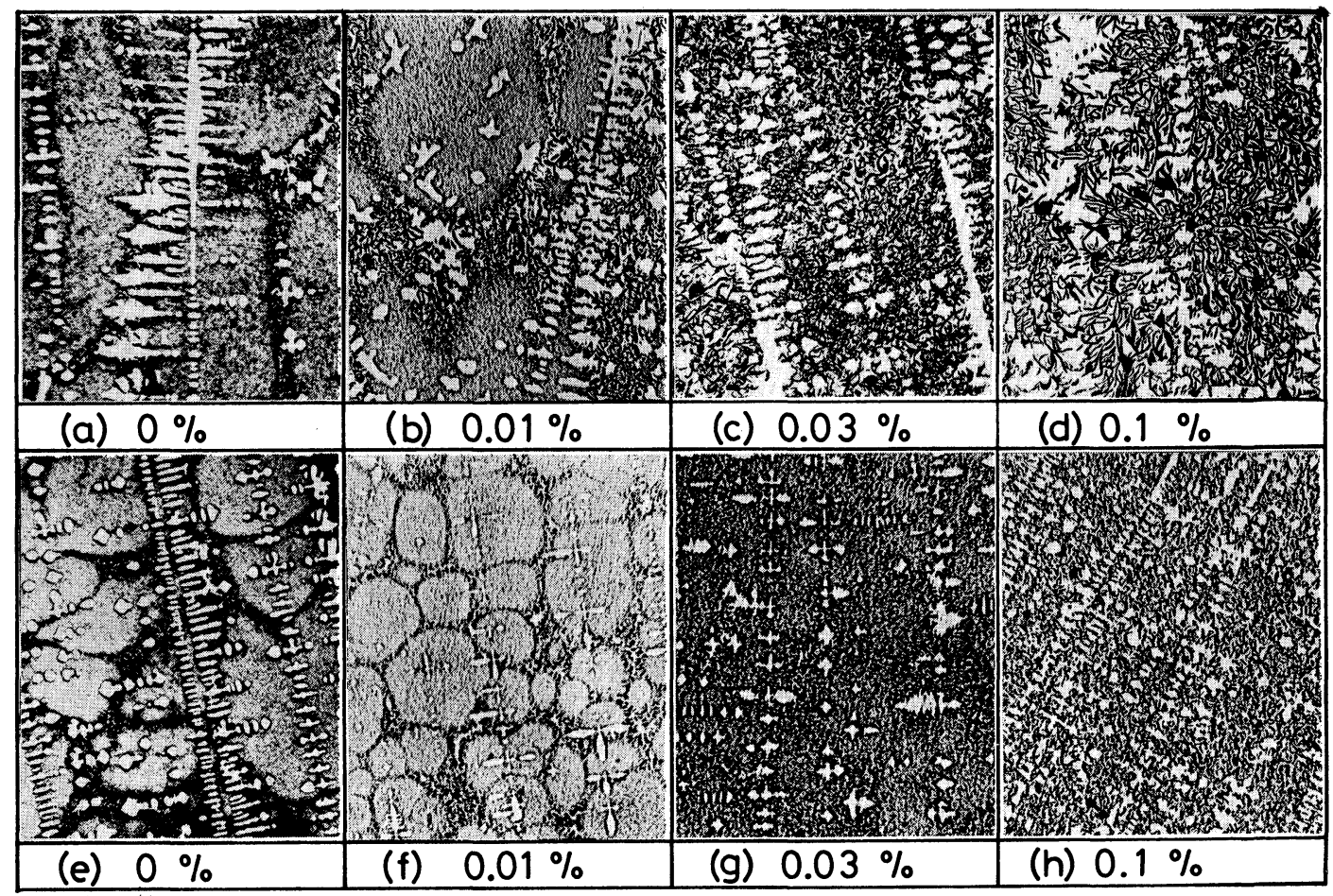

Photo. 5. Effect of sulfur on eutectic cell structure. (a) $\sim(\mathrm{d}): 2.3 \mathrm{~cm} / \mathrm{hr},(\mathrm{e}) \sim(\mathrm{h}): 13 \mathrm{~cm} / \mathrm{hr}$ 


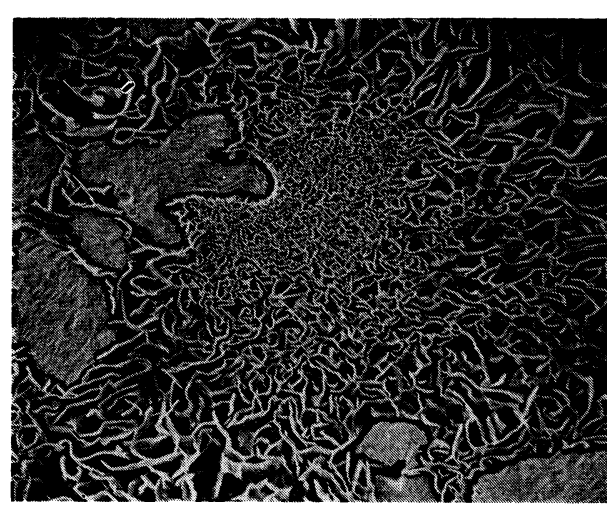

Photo. 6. Rosette graphite. $(\times 126)(\times 1 / 2)$

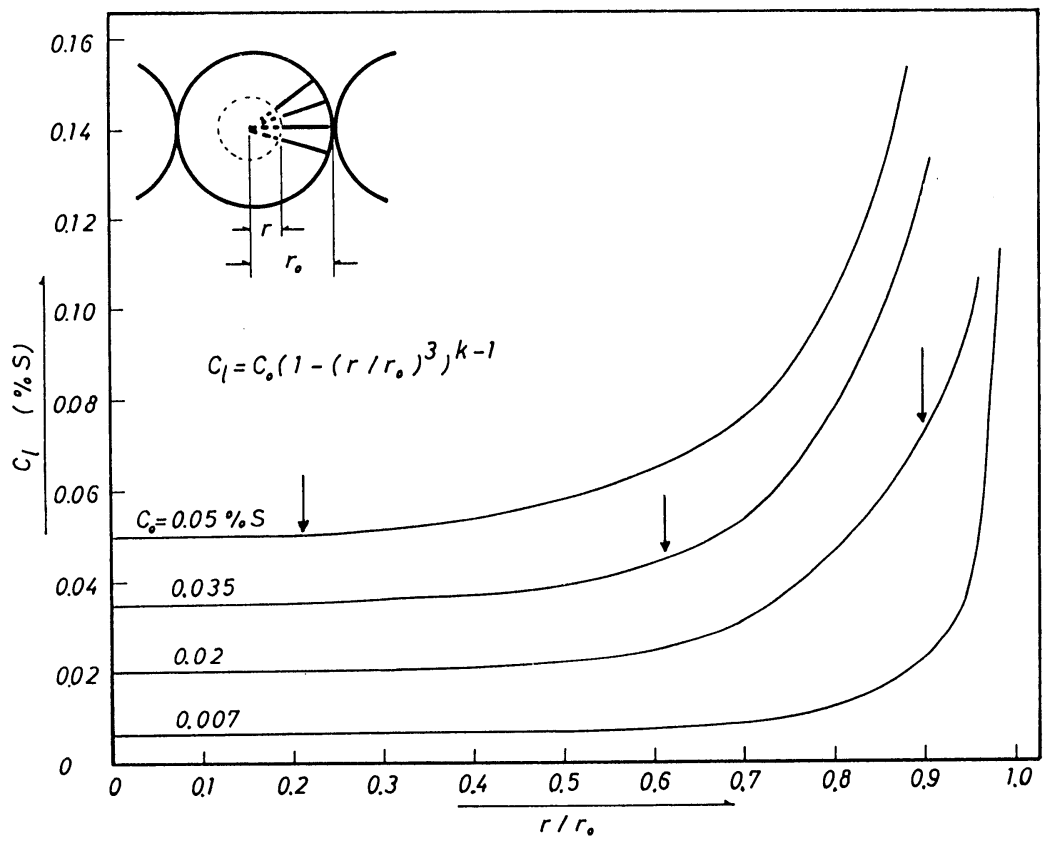

Fig. 3. Sulfur concentration of the melt in front of the solid--liquid interface. of less than $0.05 \% \mathrm{~S}$ addition, the graphite was changed from fine to coarse, when sulfur content was concentrated at $0.05 \%$ in front of the spherically growing interface.

Then, sulfur content in a liquid phase was calculated by the following equation, in order to investigate the formation of rosette, assuming that melt was stirred completely in front of the growth interface in a eutectic cell.

$$
C_{l}=C_{0}\left\{1-\left(r / r_{0}\right)^{3}\right\}^{k-1}
$$

where, $r_{0}$ : the radius of eutectic cell in the solidification structure

$r$ : radius

$C_{0}:$ initial concentration

$K$ : equilibrium distribution coefficient of sulfur.

The solid line in Fig. 3 shows the relation between $G_{l}$ and $r / r_{0}$, when $K$ is 0.02 . An indication $(\downarrow)$ shows the position of $r / r_{0}$ at various sulfur levels. $r / r_{0}$ is the transitional position at which graphite changes from fine to flaky in a eutectic cell. The values of $r / r_{0}$ are measured from the photograph of rosette graphite structure. As the transition of graphite structure was observed when sulfur content in the melt was concentrated at $0.05 \sim 0.07 \%$, the above assumption seems to have been correct.

\section{Drawing up of a Graphite Structure Diagram of Uni- directionally Solidified Iron-Graphite Eutectic}

Lakeland, ${ }^{1,2)}$ Nieswaag and Zuithoff, ${ }^{3-5)}$ and Ohira et al. ${ }^{8)}$ suggested diagrams to show the regions of macroscopic interface-planar, colony and endogenous interface, by observation of the macroscopic solid-liquid interface of unidirectionally solidified specimens. These diagrams indicate that macroscopic interface becomes less stable with increase in

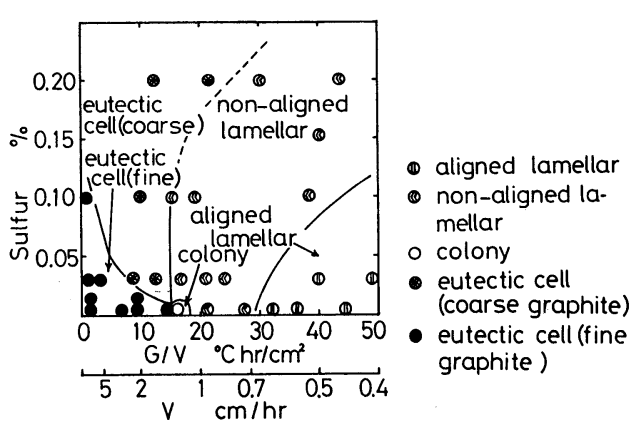

Fig. 4. Diagram of the unidirectional solidification structure.

sulfur content and solidification rate, but it was found that the region is not necessarily the same in each diagram.

In this study, the graphite structure diagram was drawn on the basis of the observation of the graphite structure which was affected by sulfur and solidification conditions instead of by the conventional investigation of solid-liquid interface.

The observation results are summarized as follows:

(1) With no sulfur addition, aligned lamellar/nonaligned lamellar/colony/eutectic cell transitions occur with increasing solidification rate.

(2) At $0.03 \% \mathrm{~S}$ addition, aligned lamellar/nonaligned lamellar/eutectic cell (coarse graphite)/eutectic cell (fine graphite) transitions occur. The colony structure was not observed.

(3) At $0.1 \% \mathrm{~S}$ addition, non-aligned lamellar/ eutectic cell (coarse graphite)/eutectic cell (fine graphite) transitions occur. Typical lamellar structure was not observed.

(4) At $0.2 \% \mathrm{~S}$ addition, non-aligned lamellar/ eutectic cell (coarse graphite) transition occurs. At higher sulfur content, this transition becomes obscure.

Figure 4 is the graphite structure diagram which 
is drawn by using above observation results (1) to (4).

\section{Effect of Titanium on the Graphite Structure ${ }^{15)}$}

1. A Diagram of the Unidirectional Solidification Structure

Photograph 7 shows the effect of titanium on the lamellar graphite structure. With an increasing titanium content, the crooked and branched graphite increases. The transition from aligned lamellar to non-aligned lamellar occurs at $0.02 \sim 0.05 \%$ Ti. Photograph 8 shows the effect of titanium on the eutectic structure. In the specimen without titanium, fine graphite and coarse graphite coexist and the eutectic cell boundary is not obscure. At contents 0.02 $0.03 \% \mathrm{Ti}$, coarse graphite disappeared and only fine eutectic graphite was observed. At contents higher than $0.03 \% \mathrm{Ti}$, the shape of fine graphite did not change further.

Figure 5 indicates the effect of titanium content and

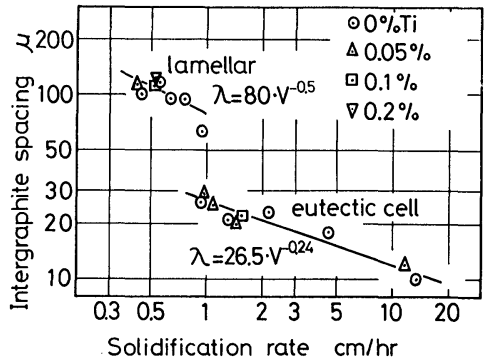

Fig. 5. Relation between intergraphite spacing and solidification rate. solidification rate $(V)$ on the intergraphite spacing $(\lambda)$. The lamellar spacing was measured at the portions of graphite which are parallel to the solidification direction and which form a group with some flakes. With an increasing titanium content, the intergraphite spacing hardly changed. Though the plots in Fig. 5 are few, the $\lambda-V$ relation $\left(\lambda^{2} \cdot V\right.$ is constant) seems to be satisfied. In the eutectic cell structure, the intergraphite spacing decreased from 30 to $10 \mu$ with an increasing solidification rate. But the intergraphite spacing showed little change at the same solidification rate with an increasing titanium content.

The diagram of the unidirectional solidification structure was drawn on the basis of the observation of graphite structure (Fig. 6). Titanium at the vertical axis was indicated by the chemically analyzed value.

(1) Eutectic structure: At a low titanium content and a low solidification rate, fine and coarse graphite structures coexist. With the addition of a small amount of titanium or a slight increase of the solidification rate, most of the graphite became fine eutectic. With an increase in titanium content, the eutectic cell boundary becomes difficult to discern.

(2) Alignment of lamellar graphite structure: The degree of alignment of lamellar graphite decreases, as the titanium content increases. As the grooves in the middle of austenitic phase in the planar interface become unstable with an increase in titanium content or solidification rate, the termination and branching of graphite will occur more vigorously. The region of aligned lamellar and non-aligned lamellar in this

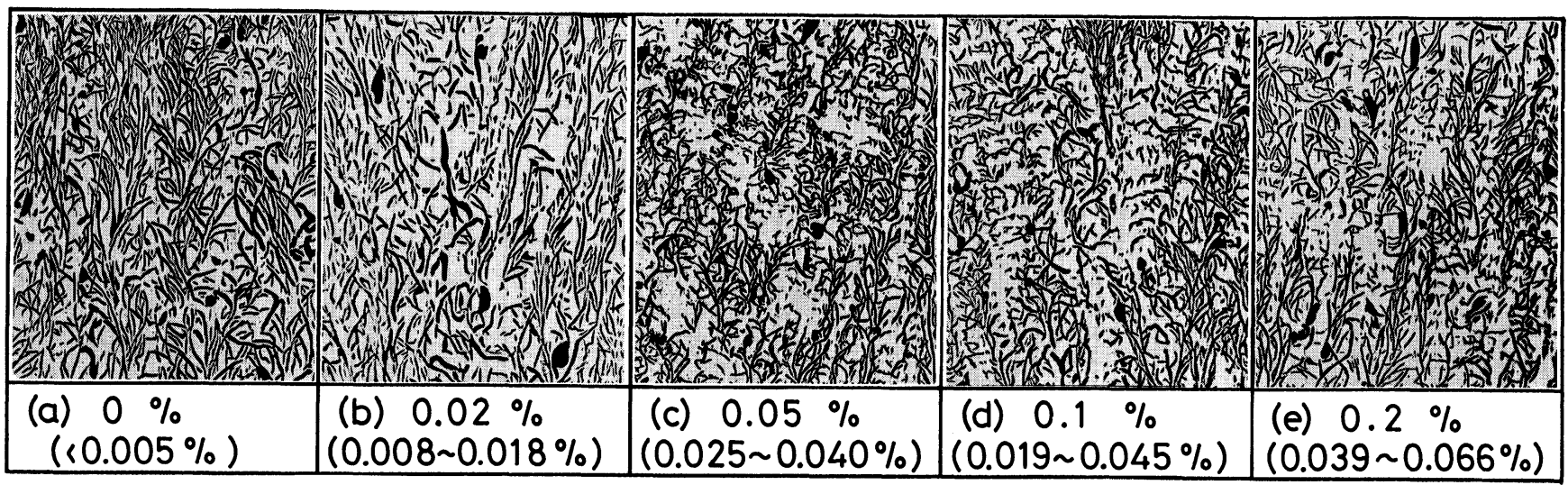

Photo. 7. Effect of titanium on lamellar graphite structure. $(\times 10)(\times 1 / 2)$

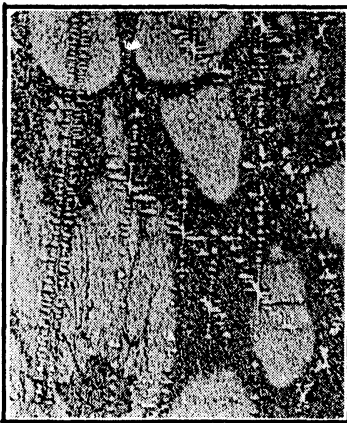

(a) $0 \%$ $(<0.005 \%)$

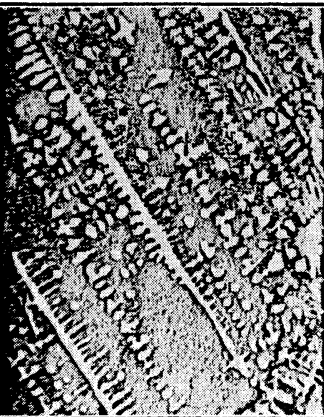

(b) $0.02 \%$ $(0.016 \sim 0.017 \%$ )

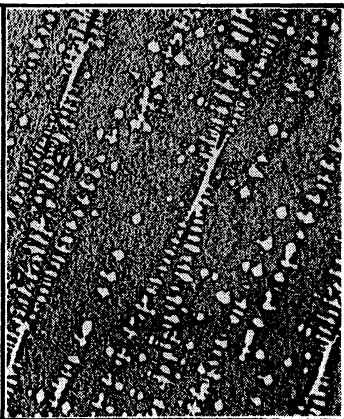

(c) $0.05 \%$ $(0.031 \sim 0.041 \%)$

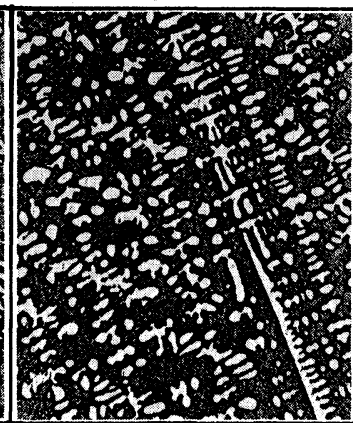

(d) $0.1 \%$ $(0.029 \sim 0.047 \%)$

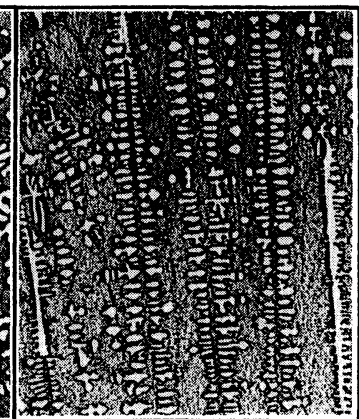

(e) $0.2 \%$ $(0.071 \sim 0.089 \%)$

Photo. 8. Effect of titanium on eutectic cell structure. $(\times 10)(\times 1 / 2)$ 


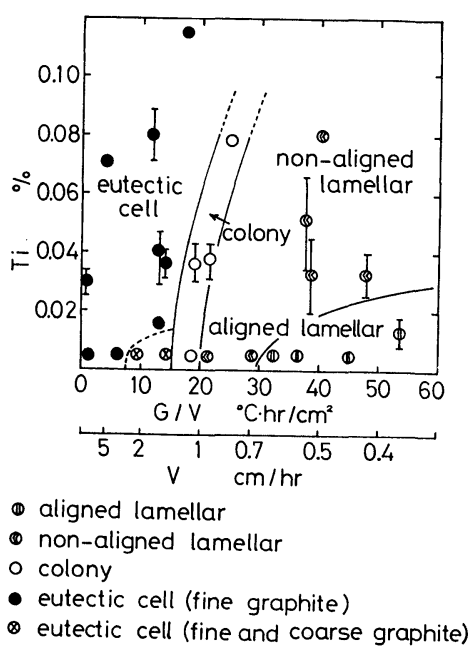

Fig. 6. Diagram of the unidirectional solidification structure.

diagram is nearly the same as in the diagram in which sulfur is added.

(3) Colony structure: In iron-graphite eutectic it is difficult to find a clear colony boundary, and sometimes is difficult to distinguish between a colony boundary and that of a eutectic cell. In the diagram in which sulfur is added, the region of colony structure is very limited (solidification rate is $1 \sim 1.5 \mathrm{~cm} / \mathrm{hr}$ and sulfur content is less than $0.01 \%$ ), because graphite flake becomes coarse with a small amount of sulfur. But in the case of titanium, the region of colony structure expanded slightly, because graphite flake tends to become eutectic graphite, and the eutectic cell boundary tends to become invisible.

\section{The Formation of Eutectic Graphite}

From the observation of three-dimensional eutectic graphite, the eutectic graphite grows radially from the apparent center site of a eutectic cell. The eutectic graphite will form a eutectic cell in this way, but it is not clear that all graphite flakes are continuous in a eutectic cell. There is a possibility that fine eutectic graphite is locally discontinuous. Assuming that eutectic graphite grows by the radial growth of austenite-graphite eutectic, three cases of graphite growth pattern in a eutectic cell were examined.

Figure 7 shows the growth mode of graphite-austenite eutectic schematically. Case (1) shows fine graphite of iron-graphite eutectic formed by cooperative growth. Both graphite and austenite grow radially and successively. Case (2) shows discontinuous graphite formed by the termination of graphite or the obstruction of the austenitic phase. ${ }^{22)}$ Case (3) shows that the austenitic groove becomes unstable with constitutional undercooling, and then graphite nucleates there. In cases (2) and (3), eutectic graphite grows discontinuously.

Many hypothetical mechanisms of eutectic graphite formation by titanium treatment have been proposed. ${ }^{20-22)}$ It is difficult to reach a conclusion at this stage of research. From our experimental results,

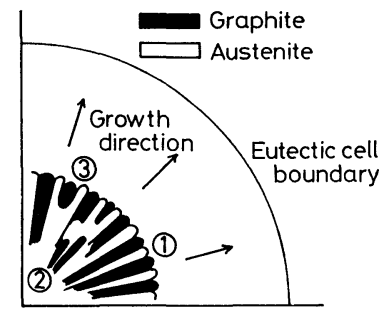

(1) Cooperative growth

(2) Termination

(3) Graphite formation at austenitic groove

Fig. 7. Schematic graphite growth in a eutectic cell.

the eutectic graphite formation mechanism seems to be explained by the change of growth mode and solidification rate. Assuming that undercooling occurs with titanium, the eutectic growth rate increases according to the following equation ${ }^{23)}$ :

$$
V=\alpha \cdot \Delta T^{2}
$$

where, $V:$ the growth rate of the eutectic

$\Delta T$ : an undercooling at the interface $\alpha$ : constant.

Intergraphite spacing will decrease from the $\lambda-V$ relation $\left(\lambda^{2} \cdot V=\right.$ constant). A decrease in the spacing has a tendency to form a fine eutectic graphite. For example, it is considered that flaky graphite will change to fine graphite with the change of growth mode from lamellar to colony.

\section{Application of Unidirectional Solidification Method-Layer Graphite Cast Iron Plate}

\section{Anisotropy of Electrical Resistance}

A lamellar graphite structure, in which graphite flakes are aligned parallel to the solidification direction, was obtained at a solidification rate not greater than $1 \mathrm{~cm} / \mathrm{hr}$. The solidification process of lamellar structure has been investigated considerably well, but there have been few experiments on its mechanical and physical properties. ${ }^{12,13,24)}$ The electrical resistance, which is related to the graphite structure, was measured in a direction either parallel or vertical to the solidification direction.

As the graphite has a hexagonal lattice structure, the electrical resistance of the direction parallel to the basal plane is quite different from that of the vertical direction. By layering the basal plane of graphite crystal through rolling, large anisotropy of electrical resistance will be observed. ${ }^{16,25,26)}$

The results of experiments at room temperature were shown in Table 3 .

(1) The electrical resistance was measured in a direction parallel or vertical to the solidification direction for the lamellar graphite structure. Since the resistance was $50 \sim 80 \mu \Omega-\mathrm{cm}$ in either direction, there was unexpectedly no anisotropy. This is because the graphite is arranged at random in a plane vertical to the solidification direction.

(2) Graphite is layered even in the vertical plane in a rolled lamellar graphite $\mathrm{Fe}-\mathrm{C}-\mathrm{Si}$ alloy. Photo- 
Table 3. Anisotropy of electrical resistance and thermal diffusivity.

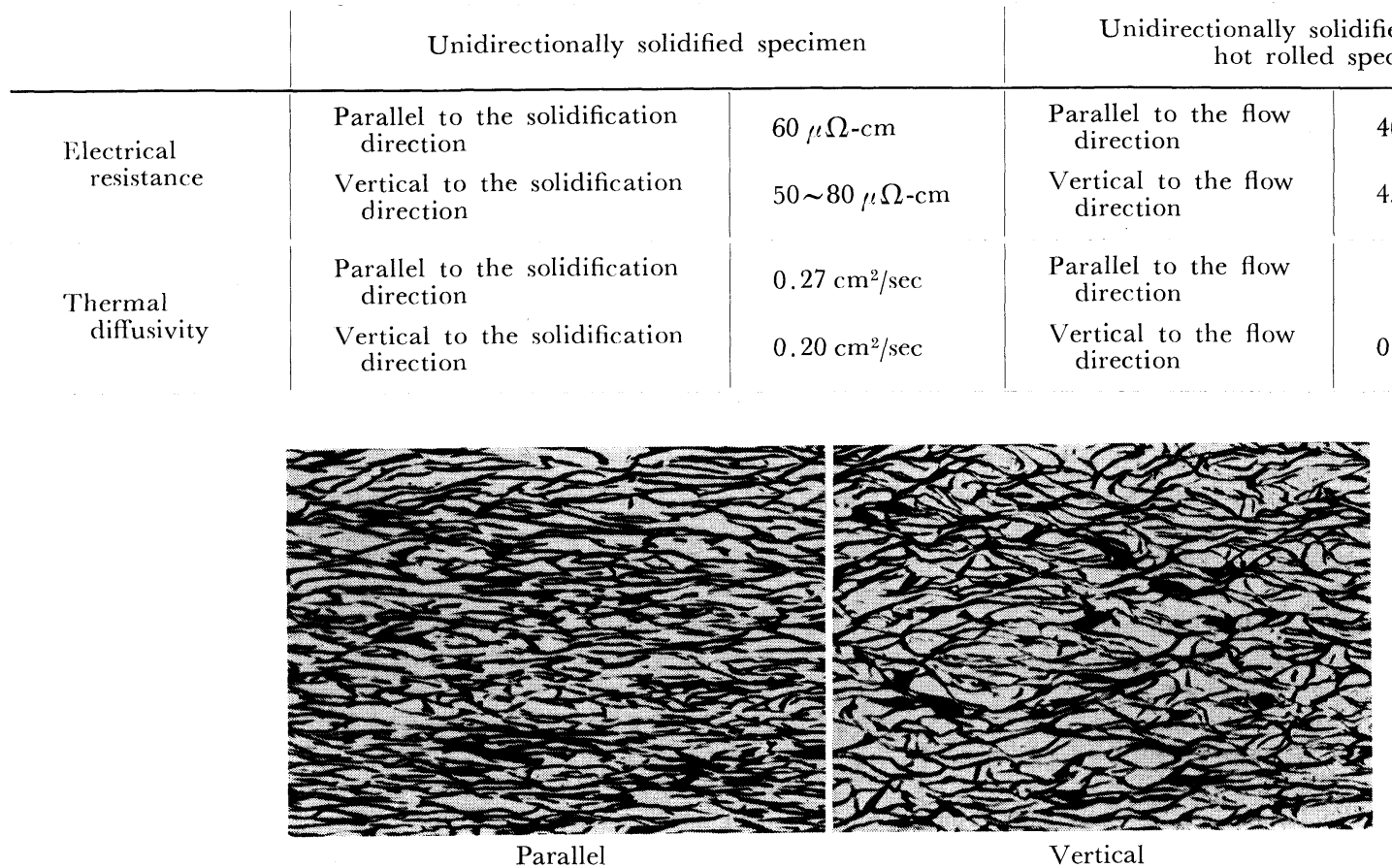

Photo. 9. Graphite structure parallel and vertical to the rolled direction. $(\times 50)\left(\times^{1 / 2}\right)$

graph 9 is graphite structure in this material. This new material (5 7 mm thick) was named "layer graphite cast iron plate".

(3) The electrical resistance in a direction vertical to the flow direction is about $10 \sim 20$ times as much as the one in a direction parallel to the flow direction.

\section{Thermal Diffusivity ${ }^{17)}$}

The measurements of thermal diffusivity at room temperature are also shown in Table 3. The thermal diffusivity in the direction parallel to the solidification direction was $0.27 \mathrm{~cm}^{2} / \mathrm{sec}$, but the thermal diffusivity in the direction vertical to the flow direction was $0.04 \mathrm{~cm}^{2} / \mathrm{sec}$. The thermal diffusivity in the direction vertical to the layered flaky graphite was extremely low. It was shown that the thermal diffusivity was affected by the array of flaky graphite. As the thickness of the rolled material was only $5 \mathrm{~mm}$, the diffusivity in the direction parallel to the flow direction could not be measured. But, assuming that the diffusivity in the direction parallel to the flow direction is the same as that in the direction parallel to the solidification direction, an anisotropy of thermal diffusivity will also exist in this "layered graphite cast iron plate."

\section{Summary}

This paper describes the unidirectional solidification experiments which were carried out in order to investigate the effects of sulfur, titanium and solidification rate.

(1) Effect of sulfur on the solidification structure of iron-graphite eutectic was investigated. In the eutectic containing sulfur of less than $0.02 \%$, the graphite structure changes from aligned lamellar to non-aligned lamellar, colony, eutectic cell (fine graphite), successively, with an increase in the solidification rate. In the eutectic containing over $0.10 \%$, the graphite structure changes from non-aligned lamellar to eutectic cell (flaky graphite), eutectic cell (fine graphite), successively, with an increase in the solidification rate. But the transition of non-aligned lamellar to eutectic cell was not so clear when the sulfur content was very high. A diagram of the unidirectional solidification structure was drawn using these experimental results.

(2) It became clear by the calculation of the sulfur content in front of the spherically growing eutectic interface, that the rosette graphite structure was formed by the transition from fine to coarse graphite when sulfur content was concentrated to $0.05 \sim$ $0.07 \% \mathrm{~S}$. The formation of rosette graphite was discussed.

(3) The effect of sulfur on the lamellar graphite spacing was examined. It was recognized that the spacing increases in a low sulfur range, and it decreases in a high sulfur range.

(4) The effects of titanium on the graphite structure were investigated. A diagram of the unidirectional solidification structure was drawn from the observation of graphite structure. The effects of titanium on the lamellar/colony/eutectic cell transition and on the alignment of lamellar graphite were studied. Although the fine eutectic graphite in eutectic cells was three-dimensionally continuous in most cases, it was discontinuous in some cases. However, eutectic cells are formed by radial growth of austenite-graphite eutectic in either case.

The mechanism of fine eutectic graphite formation was discussed. It was related to the changes 
in growth morphology and the solidification rate, brought about by the addition of titanium.

(5) As a result of the application of the unidirectional solidification technique, a new material-“ layer graphite cast iron plate" was made in Kobe Steel's Central Research Laboratory. The physical anisotropic characteristics of this material have been described mainly with reference to the electrical resistance and thermal conductivity. It is expected that this material will be used in various fields for application requiring electric resistance and thermal conductivity.

\section{REFERENCES}

1) K. D. Lakeland: J. Aus. Inst. Metals, 10 (1965), 55.

2) K. D. Lakeland: Recent Research on Cast Iron, Gordon and Breach, New York, (1964), 417.

3) H. Nieswaag and A. J. Zuithoff: AFS Cast Metal R.J., (1970), 21 .

4) H. Nieswaag and A. J. Zuithoff: The Metallurgy of Cast Iron, Georgi Publishing Co., Switzerland, (1975), 327.

5) H. Nieswaag and A.J. Zuithoff: Giesserei Forshung, 26 (1974), 19.

6) Y. Sayama, T. Sato and G. Chira: J. Crystal Growth, 22 (1974), 272.

7) T. Sato and Y. Sayama: J. Crystal Growth, 22 (1974), 259.

8) G. Ohira, T. Sato and Y. Sayama: The Metallurgy of Cast Iron, Georgi Publishing Co., Switzerland, (1975), 295.

9) M. Ibaragi, T. Okamoto and K. Matsumoto: J. Japan Inst. Metals, 31 (1967), 690.

10) T. Owadano, K. Kishitake, M. Fujii and Y. Kanekawa:
Imono (J. Japan Foundrymen's Soc.), 50 (1978), 101.

11) T. Sakamoto, K. Yoshikawa, C. Yoshida, J. Nakamura, T. Mori and H. Takada: Trans. ISIJ, 20 (1980), 629.

12) C. Yoshida, K. Yoshikawa, T. Sakamoto, T. Mori and H. Takada: Imono (J. Japan Foundrymen's Soc.), 50 (1978), 715.

13) K. Yoshikawa, C. Yoshida, T. Sakamoto, T. Mori and H. Takada: Imono (J. Japan Foundrymen's Soc.), 51 (1979), 11.

14) C. Yoshida, T. Sakamoto, T. Ito and H. Takada: Imono (J. Japan Foundrymen's Soc.), 51 (1979), 76.

15) C. Yoshida, T. Sakamoto and T. Ito: Imono (J. Japan Foundrymen's Soc.), 54 (1982), 277.

16) G. Yoshida, T. Sakamoto, T. Ito, T. Mori and H. Takada: Trans. ISIJ, 21 (1981), 187.

17) M. Sasaki, K. Taniguchi, C. Yoshida and T. Sakamoto: Imono (J. Japan Foundrymen's Soc.), 55 (1983), 219.

18) T. Yanagisawa and M. Maruyama: Imono (J. Japan Foundrymen's Soc.), 48 (1976), 681.

19) M. Ibaragi, T. Okamoto and K. Matsumoto: Imono ( $J$. Japan Foundrymen's Soc.), 38 (1966), 808.

20) H. Sawamura: Imono ( J. Japan Foundrymen's Soc.), 31 (1959), 486.

21) W. Oldfield: BCIRA J., 8 (1960), 177.

22) S. Nishikawa, S. Yamamoto and Y. Kawano: Imono ( $J$. Japan Foundrymen's Soc.), 49 (1977), 525.

23) B. Lux and W. Kurz: The Solidification of Metals, ISI, London, (1967), 193.

24) K. V. Prabhakar, H. Nieswaag and A. J. Zuithoff: Sheffield International Conference on Solidification and Casting, Sheffield Met. and Eng. Assoc., Sheffield Univ., (1977), 68.

25) C. Yoshida and T. Mori: US Patent No. 4080715, (1978).

26) C. Yoshida and T. Mori: Japan Patent No. 56-50771, (1981). 